\title{
The Potential of Outing Class Activities to Enhance Environmental Awareness for Elementary School Pre-Services Teacher
}

\author{
Patonah, S. ${ }^{1}$, Rahardjo, S. B. ${ }^{2}$, Cari $^{3}$, Sajidan $^{4}$ \\ ${ }^{1}$ Student of Doctor Program Natural Science Education Universitas Sebelas Maret, Indonesia \\ ${ }^{2,3,4}$ Doctoral Program Natural Science Education Universitas Sebelas Maret, Indonesia
}

Corresponding email: sitifatonah@upgris.ac.id

\begin{abstract}
Environmental damage in various places requires concrete steps to be resolved. The purpose of this research is to make environmental awareness work for Elementary School Pre-services Teacher through outing class activities. Post-test only group design is used as a method of this research. The instruments used are environmental awareness questionnaire where adapted. There are 71 elementary pre-service teachers (60 male and 11 female) who fill in questioner. Students divide into 2 groups: experiment group and control group. Data analysis is an independent sample test using SPSS vol. 22. Experiment group, learning is done by outing class while the control group is done in the classroom. The obtained significance of $0.029<0.05$, indicating that there is a difference between the experimental group and the control group. Outing class has an effect on environmental awareness to the elementary school pre-service teacher. An indepth study is required to modify outing class activities in enhancing environmental awareness.
\end{abstract}

Keywords: outing class; environmental awareness; elementary school; PreServices Teacher

DOI: $10.20961 /$ ijpte.v\%vi\%i.19764 


\section{INTRODUCTION}

Education is the root of all changes (Freije, Hussain, \& Salman, 2015; Alfuhaigi, 2015). Education becomes the determinant of success for a nation (Liefländer, Bogner, Kibbe, \& Kaiser, 2015). Among the problems that are and in accordance with human activities are energy and environmental issues. Environmental problems are complex issues on all sides (Palmer, 1998; Ostrom et al., 2002). Each side needs a concrete solution to overcome. In addition, the environment is also included in the triple bottom line (TBL), which is the principle of sustainable development (Fiselier, Longhurst, \& Gough, 2017; Govindan, Khodaverdi, \& Jafarian, 2013). TBL consists of 3 components namely environmental, economic, and social, which are interconnected. Economic aspects that are not paid attention to social aspects and aspects of the environment, vice versa.

Overcoming environmental problems is not enough just with theory alone, but important to be realized as a concrete step in everyday life. Habits in everyday life can be trained through education. In fact, in some countries, education on survival is important in schools (Jones \& Mixon, 2017). While in the country of Indonesia, environmental education is still a material distraction that integrates with other materials.

A good teacher preparation is one of the keys to the achievement of good environmental education. The teacher is the spearhead of an educational success (Chen \& Tsai, 2016; Ocetkiewicz, Tomaszewska, \& Mróz, 2017). Especially at the primary school level, the introduction of keeping the environment is very important teaching from an early age (Klöckner, 2013; Saribas, Teksoz, \& Ertepinar, 2014). The preparation of teachers who can prepare an environmentally conscious generation is a matter of concern.

Comprehensive understanding of prospective elementary school teachers on environmental issues and how to address them are the main things that need to be understood. A prospective teacher should know the immediate conditions that exist in the environment, so as to take appropriate steps. Learning is not only limited to the room but also conducting activities directly in the field (outing class). Through out-of-class learning, it is hoped that prospective elementary teachers can increase environmental awareness. Prospective teachers are directly involved in environmental issues, not just introductions or introductions (Hadzigeorgiou \& Skoumios, 2013). Therefore the university has a strategic role to be able to build an environmentally-based joint research that will ultimately be highly beneficial for future teachers in future careers (Monk et al., 2014; Karataş, 2014). Outing class is an effective means to bring prospective teachers closer to real issues around so that an appropriate solution can be pursued.

Learning outside the classroom requires several supporting components, including clarity of activities to be implemented, learning model to be done and so forth. Through learning outing class, students are expected to have direct experience that has an effect on the emergence of a positive attitude on the environment, namely environmental awareness. The purpose of this study is to determine whether there is a difference in environmental awareness of students who learn in outing class and without outing class. 


\section{METHOD}

\section{Participant}

There are 71 students (60 female students and 11 male students) who are in the sixth semester of pre-service teacher elementary school Universitas PGRI Semarang Central Java, Indonesia Academic Year 2016/2017 even. The sample is divided into 2 different groups. The method used in this research is post-test only group design. Both groups were given a questionnaire of environmental concern after completion of the lesson.

\section{Measures}

All participants answered a questionnaire about environmental concerns consisting of 60 items within 30 minutes. The environmental concern questionnaire was adapted from a questioner developed by Teknologi University Malaysia (Mei, Wai, \& Ahamad, 2016). Questionnaires use Likert scale 1 to 5, where 5 for "strongly agree" statements, 4 for "agree", 3 "for neutral statements", 2 for "disagree" statements, and 1 for "strongly disagree" statements.

\section{Procedures}

Group 1 is a control group where in this class, learning about energy and the environment is only given in the classroom. Students discuss the materials prepared by the researchers without seeing any real environmental problems. Group 2 is an experimental group. Students conduct observations/ surveys on energy and environmental issues on campus during the previous one, then at the next meeting to discuss the solution when learning in the classroom. Students are given a worksheet to record their findings and gather information to solve environmental and energy problems under conditions encountered.

\section{Data Analysis}

Analyze the data using SPSS vol.22 to know the difference between both types of learning that is using independent sample test. The data obtained were analyzed using 5\% significance level (0.05).

\section{RESULT}

Finding 2.1. Environmental awareness of the experimental class and control class

The environmental care of prospective elementary school teachers after the learning activities is shown in Figure 1.

2.2. Analysis data independent sample test using SPSS vol.22

Data analysis using SPSS vol.22 is shown in Table 1 and Table 2 
Table 1 Description of Data

\begin{tabular}{|l|c|c|c|c|c|}
\hline \multicolumn{1}{|c|}{} & Group & $\mathrm{N}$ & Mean & Std. Deviation & Std. Error Mean \\
\hline \multirow{2}{*}{ E.Awareness } & 1,00 & 29 & 216,9310 & 18,84889 & 3,50015 \\
\cline { 2 - 6 } & 2,00 & 42 & 225,4048 & 13,45645 & 2,07638 \\
\hline
\end{tabular}

Table 2 Out put analysis data

Independent Samples Test

\begin{tabular}{|c|c|c|c|c|c|c|c|c|c|c|}
\hline & \multicolumn{2}{|c|}{$\begin{array}{l}\text { Levene's Test } \\
\text { for Equality of } \\
\text { Variances }\end{array}$} & \multicolumn{7}{|c|}{ t-test for Equality of Means } \\
\hline & & \multirow[b]{2}{*}{$\mathrm{F}$} & \multirow[b]{2}{*}{ Sig. } & \multirow[b]{2}{*}{$\mathrm{t}$} & \multirow[b]{2}{*}{ df } & \multirow{2}{*}{$\begin{array}{l}\text { Sig. (2- } \\
\text { tailed) }\end{array}$} & \multirow{2}{*}{$\begin{array}{c}\text { Mean } \\
\text { Difference }\end{array}$} & \multirow{2}{*}{$\begin{array}{l}\text { Std. Error } \\
\text { Difference }\end{array}$} & \multicolumn{2}{|c|}{$\begin{array}{l}95 \% \text { Confidence } \\
\text { Interval of the } \\
\text { Difference }\end{array}$} \\
\hline & & & & & & & & & Lower & Upper \\
\hline \multirow[t]{2}{*}{ E.Awareness } & $\begin{array}{l}\text { Equal } \\
\text { variances } \\
\text { assumed }\end{array}$ & ,772 & ,383 & $-2,212$ & 69 &, 030 & $-8,47373$ & 3,83094 & $-16,11625$ &,- 83121 \\
\hline & $\begin{array}{l}\text { Equal } \\
\text { variances } \\
\text { not } \\
\text { assumed }\end{array}$ & & & $-2,082$ & 47,184 & ,043 & $-8,47373$ & 4,06969 & $-16,66005$ &,- 28741 \\
\hline
\end{tabular}

The level of students' environmental awareness in the experimental class and the control class is shown on the Figure. 1. Based on graph one then it can be seen that the environmental awareness in the control class is lower than the experimental class.

\section{Environmental Awareness}

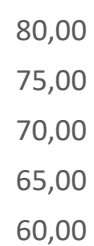

60,00

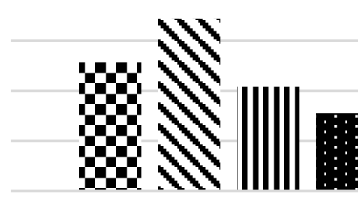

Experiment Group

- EA for water use

II EA of waste
Control Group

'EA for energi use

EA of animal and plant

Note:

$\mathrm{EA}=$ environmental awareness

Figure 1. The level of environmental awareness

\section{DISCUSSION}

Group 1 is a control group wherein this group environmental studies do not conduct field surveys (not outing classes), but only lecture and discussion lessons in the classroom. While in the experimental class conducted learning outside the 
class then discussed than to the field again to test the results of their discussions in addressing environmental issues. Students conduct surveys and direct observations in the field where environmental problems are found before they attend classroom learning. Based on SPSS analysis vol. 22 the SD for the experimental class is smaller than the control class $(18.84<13.45)$ as well as for SEM also obtained smaller numbers compared to SEM in the control group. This indicates that the distribution of environmental concerns in the experimental class is better than the control class.

For the independent sample test, it is shown that the Leven's test value is not significant because the value is greater than $0.05(0.383)$, meaning that the variance in both groups is the same. The $t$ value at 2.212 indicates with a significance of $0.030(<0.05)$, indicating that the environmental concerns of the two groups differed significantly. This means that the outing class activities affect the environmental awareness of the prospective primary school teacher. In line with this result, it is a graph 1 that shows the overall level of concern of student teacher candidates in the experimental class compared to the control class. These results are in accordance with what has been done by (Gray \& Thomson, 2016), environmental learning is very potential to cultivate environmental awareness when done learning outside the classroom. Through out-of-school learning, students also show their creativity when they provide solutions to problems. A direct observation of environmental issues outside the classroom can help prospective primary teachers better recognize environmental problems that can ultimately provide an appropriate solution. Learning outside the classroom can be recommended to be given to prospective elementary school teachers in preparing them to have environmental concerns and to educate them on future students.

\section{CONCLUSION}

Outing class learning contributes significantly to growing environmental awareness among primary school student candidates. The environmental concerns of prospective teachers are higher on the lessons learned by outing the class and those not.

\section{ACKNOWLEDGMENTS}

Acknowledgments of infinity for the publication of this article, grant PNBP UNS Year 2017 with document number 623 / UN27.21 / PP / 2017.

\section{REFERENCES}

Balasubramanian, K., Jaykumar, V., \& Fukey, L. N. (2014). A study on "student preference towards the use of Edmodo as learning platform to create responsible learning environment." Procedia - Social and Behavioral Sciences 144, $416-422$.

Alfuhaigi, S. S. (2015). School Environment and Creativity Development: a Review of Literature. Journal of Educational and Instructional Studies in the World, 5(2), 33-38. 
Chen, C. L., \& Tsai, C. H. (2016). Marine environmental awareness among university students in Taiwan: a potential signal for sustainability of the oceans. Environmental Education Research, 22(7), 958-977. https://doi.org/10.1080/13504622.2015.1054266

Fiselier, E. S., Longhurst, J. W. S., \& Gough, G. K. (2017). Exploring the current position of ESD in UK higher education institutions. International Journal of Sustainability in Higher Education, IJSHE-06-2017-0084. https://doi.org/10.1108/IJSHE-06-2017-0084

Freije, A. M., Hussain, T., \& Salman, E. A. (2015). Global warming awareness among the University of Bahrain science students. Journal of the Association of Arab Universities for Basic and Applied Sciences, 9-16. https://doi.org/10.1016/j.jaubas.2016.02.002

Govindan, K., Khodaverdi, R., \& Jafarian, A. (2013). A fuzzy multi criteria approach for measuring sustainability performance of a supplier based on triple bottom line approach. Journal of Cleaner Production, 47, 345-354. https://doi.org/10.1016/j.jclepro.2012.04.014

Gray, T., \& Thomson, C. (2016). Transforming Environmental Awareness of Students Through the Arts and Place-Based Pedagogies, 9(2), 239-260.

Hadzigeorgiou, Y., \& Skoumios, M. (2013). The development of environmental awareness through school science: Problems and possibilities. International Journal of Environmental \& Science Education, 8(3), 405-426. https://doi.org/10.12973/ijese.2013.212a

Karataş, A. (2014). Environmental ethics education as a tool for the prevention of environmental problems in the community. European Journal of Sustainable Development, 3(4), 263-268. https://doi.org/10.14207/ejsd.2014.v3n4p263

Klöckner, C. a. (2013). A comprehensive model of the psychology of environmental behavior - A meta-analysis. Global Environmental Change, 23(5), 1028-1038. https://doi.org/10.1016/j.gloenvcha.2013.05.014

Liefländer, A. K., Bogner, F. X., Kibbe, A., \& Kaiser, F. G. (2015). Evaluating Environmental Knowledge Dimension Convergence to Assess Educational Programme Effectiveness. International Journal of Science Education, 37(4), 684-702. https://doi.org/10.1080/09500693.2015.1010628

Mei, N. S., Wai, C. W., \& Ahamad, R. (2016). Environmental Awareness and Behaviour Index for Malaysia. Procedia - Social and Behavioral Sciences, 222(7), 668-675. https://doi.org/10.1016/j.sbspro.2016.05.223

Monk, M. H., Baustian, M. M., Saari, C. R., Welsh, S., Elia, C. F. D., Powers, J. E., \& Gaston, S. (2014). EnvironMentors : Mentoring At-Risk High School Students through University Partnerships, 9(4), 385-397. https://doi.org/10.12973/ijese.2014.223a

Ocetkiewicz, I., Tomaszewska, B., \& Mróz, A. (2017). Renewable energy in education for sustainable development. The Polish experience. Renewable 
and Sustainable Energy Reviews, 80(May), 92-97. https://doi.org/10.1016/j.rser.2017.05.144

Ostrom, E., Dietz, T., Dolsak, N., Stern, P. C., Stonich, S., \& Weber, E. U. (2002). The Drama of the Commons. https://doi.org/10.17226/10287

Palmer, J. (1998). Environmental education in the 21st Century.

Saribas, D., Teksoz, G., \& Ertepinar, H. (2014). The relationship between environmental literacy and self-efficacy beliefs toward environmental education, 116, 3664-3668. https://doi.org/10.1016/j.sbspro.2014.01.820 
International Journal of Pedagogy and Teacher Education (IJPTE) (Vol. 2 | Focus Issue-January 2018) 